\title{
Faktor-Faktor yang Mempengaruhi Perilaku Gangguan Kecanduan Game Online pada Peserta Didik Kelas X di Madrasah Aliyah Al Furqon Prabumulih Tahun Pelajaran 2015/2016
}

\author{
Hardiyansyah Masya, Dian Adi Candra
}

Dosen Fakultas Tarbiyah dan Keguruan, IAIN Raden Intan Lampung

Diterima: 27 Januari 2016. Disetujui: 12 Maret 2016. Dipublikasikan: Mei 2016

\begin{abstract}
Abstrak: Artikel ini berisikan tentang faktor-faktor yang mempengaruhi perilaku gangguan kecanduan game online pada peserta didik. game online sendiri mempunyai Salah satu penyimpangan yang dilakukan oleh remaja akibat kecanduan game online antara lain berbohong. Kebiasaan berbohong ini disebabkan karena remaja yang notabene masih peserta didik mendapatkan uang dari orang tuanya. Jika mereka mengatakan secara terus terang meminta uang untuk bermain game online, tentu orang tua sulit untuk memberikannya. Dengan alasan itulah akhirnya banyak remaja memilih berbohong. Banyaknya waktu yang dihabiskan dengan bermain games dapat berpengaruh terhadap perilaku remaja antara lain malas. Selain itu, berbagai game online kerap kali membutuhkan uang untuk membeli senjata-senjata game, sehingga tidak menutup kemungkinan pengguna yang mayoritas masih pelajar berbohong kepada orang tua dengan berbagai alasan agar dapat memenuhi hobinya bermain game online. Perubahan perilaku pada remaja yang mengalami kecanduan game online mungkin tidak dirasakan oleh remaja itu sendiri, tetapi dapat dirasakan oleh orang lain dilingkungan mereka khususnya orang tua, hal tersebut dibuktikan dengan banyaknya remaja sering membolos dan menghabiskan waktu di depan computer dari pada buku, sehingga menyebabkan aktivitas sekolahnya terganggu. Tujuan dari penelitian ini adalah menjelaskan dan mendiskripsikan faktor-faktor penyebab remaja lebih suka game online. Penelitian ini dilakukan dengan menggunakan metode kuantitatif, Penelitian ini dilaksanakan di MA Al Furqon Prabumulih tahun pelajaran 2015/2016 pada 26 Februari sampai dengan 26 Maret sesuai dengan jadwal yang disepakati. Subjek dalam penelitian ini adalah seluruh peserta didik kelas X MA Al-Furqon Prabumulih sebanyak 53 peserta didik. Berdasarkan hasil penelitian terdapat enam indikator factor-faktor yang mempengaruhi, antara sebagai berikut: Kurangnya perhatian dari orang-orang terdekat, depresi, kurang control, kurang kegiatan, lingkungan dan pola asuh.
\end{abstract}

Kata kunci: Game online; Prilaku Kecanduan

\section{Pendahuluan}

Kemajuan teknologi informasi dankomunikasi yang sangat pesat menuntut kita untuk jeli memilah dan memilih berbagai informasi yang kita terima. Salah satu dampak dari kemajuan teknologi adalah internet. Berbagai informasi dapat diakses melalui internet secara bebas. Tidak hanya informasi, berbagai sarana hiburan juga disajikan oleh internet. Salah satunya adalah game online. Games Online saat ini tidaklah sama seperti ketika games online diperkenalkan untuk pertama kalinya. Pada saat muncul pertama kalinya tahun 1960, komputer hanya bisa dipakai untuk dua orang saja untuk bermain game. Lalu muncullah komputer dengan kemampuan time-sharing sehingga pemain yang bisa memainkan game tersebut bisa lebih banyak dan tidak harus berada di suatu ruangan yang sama (Multiplayer Games). Salah satu penyimpangan yang dilakukan oleh remaja akibat kecanduan game online antara lain berbohong. Kebiasaan berbohong ini disebabkan karena remaja yang notabene masih peserta didik mendapatkan uang dari orang tuanya. Jika mereka mengatakan secara terus terang meminta uang untuk bermain game online, tentu orang tua sulit untuk memberikannya. Dengan alasan itulah akhirnya banyak remaja memilih berbohong. Banyaknya waktu yang dihabiskan dengan bermain games dapat berpengaruh terhadap perilaku remaja antara lain malas. Selain itu, berbagai game online kerap kali membutuhkan uang untuk membeli senjata-senjata game, sehingga tidak menutup kemungkinan pengguna yang mayoritas masih pelajar berbohong kepada orang tua dengan berbagai alasan agar dapat memenuhi hobinya bermain game online. Perubahan perilaku pada remaja yang mengalami kecanduan game online mungkin tidak 
dirasakan oleh remaja itu sendiri, tetapi dapat dirasakan oleh orang lain dilingkungan mereka khususnya orang tua.

Game online, kata yang sering digunakan untuk merepresentasikan sebuah permainan digital yang sedang marak di zaman yang modern ini. Game online ini banyak dijumpai di kehidupan sehari-hari. Walaupun beberapa orang berpikir bahwa game online identik dengan Komputer, game tidak hanya beroperasi di komputer. Game dapat berupa konsol, handled, bahkan game juga ada di telepon genggam. Game online berguna untuk refreshing atau menghilangkan rasa jenuh si pemain baik itu dari kegiatan sehari-hari (kerja, belajar, dan faktor lainnya) maupun sekadar mengisi waktu luang.

Tipe-tipe game online terdiri dari beberapa bentuk diantaranya yaitu:

1. First Person Shooter (FPS)

Game ini mengambil pandangan orang pertama pada gamernya sehingga seolah-olah pertama pada gamernya sehingga seolah-olah kita sendiri yang berada dalam game tersebut, kebanyakan game ini mengambil setting peperangan dengan senjata-senjata militer (di Indonesia game jenis ini sering disebut game tembak- tembakan).

2. Real-Time Strategy

Merupakan game yang permainanya menekankan kepadakehebatan strategi permainanya, biasanya permainan memainkan tidak hanya 1 karakter saja akan tetapi banyak karakter.

3. Croos-Platform Online

Game yang dapat dimainkan secara online dengan hardware yang berbeda misalnya saja need for speed undercorver dapat dimainkan secara online dari PC maupun hardware/console game yang memiliki konektivitas ke internet sehingga dapat bermain secara online).

4. Browser games

Merupakan game yang dimainkan pada browser seperti firefox, opera, IE. Syarat dimana sebuah browser dapat memainkan game ini adalah browser sudah mendukung javascript, php, maupun flash.

5. Massive Multiplayer Online Games

Adalah game dimana pemain bermain dalam dunia yang skalanya besar (>100 pemain), setiap pemain dapat berinteraksi langsung seperti halnya dunia nyata.

Dampak perkembangan teknologi diantaranya adalah perkembangan jaringan internet. Dengan adanya perkembangan internet berkembanglah teknologi salah satunya adalah munculnya game online. Agustinus Nilwan mengemukakan game merupakan permainan komputer yang dibuat dengan teknik dan metode animasi. Jika ingin mendalami pengunaan animasi haruslah memahami pembuatan game. Atau jika ingin membuat game, maka haruslah memahami teknik dan metode animasi, sebab keduanya saling berkaitan. Sampai saat ini, teknologi telah memungkinkan terobosan besartentang media imajinasi yang saling terkait dengan interaksi. Game merupakan salah satu artefak abad 21 yang telah menghasilkan pemahaman besar tentang nilai spirit juang dalam sebuah daya interaktif buatan. Abad teknologi telah menciptakan peradaban terpenting dalam hidup manusia, manusia menciptakan ketidakpastian interaksi kedalam suatu dunia buatan.

Adapun beberapa dampak negatif dan positif game online bagi pelajar, dampak positif dari game online bagi pelajar adalah:

1. pergaulan peserta didik akan lebih mudah diawasi oleh orang tua;

2. otak peserta didik akan lebih aktif dalam berfikir;

3. reflek berfikir dari peserta didik akan lebih cepat merespon;

4. emosional peserta didik dapat di luapkan dengan bermain game; dan

5. peserta didik akan lebih berfikir kreatif. 
Sedangkan dampak negatif dari game online bagi pelajar adalah:

1. peserta didik akan malas belajar dan sering menggunakan waktu luang mereka untuk bermain game online;

2. peserta didik akan mencuri curi waktu dari jadwal belajar mereka untuk bermain game online;

3. waktu untuk belajar dan membantu orang tua sehabis jam sekolah akan hilang karena maen game online;

4. uang jajan atau uang bayar sekolah akan diselewengkan untuk bermain game online;

5. lupa waktu;

6. pola makan akan terganggu;

7. emosional peserta didik juga akan terganggu karena efek game ini;

8. jadwal beribadahpun kadang akan dilalaikan oleh peserta didik; dan

9. peserta didik cenderung akan membolos sekolah demi game kesayangan mereka.

Dampak positif dari game online bagi pelajar adalah pergaulan siswa akan lebih mudah di awasi oleh orang tua, otak siswa akan lebih aktif dalam berfikir, reflek berfikir dari siswa akan lebih cepat merespon, emosional siswa dapat di luapkan dengan bermain game, siswa akan lebih berfikir kreatif. Dampak negatif dari game online bagi pelajar adalah siswa akan malas belajar dan sering menggunakan waktu luang mereka untuk bermain game online, siswa akan mencuri curi waktu dari jadwal belajar mereka untuk bermain game online, waktu untuk belajar dan membantu orang tua sehabis jam sekolah akan hilang karena maen game, uang jajan atau uang bayar sekolah akan di selewengkan untuk bermain game online, lupa waktu Pola makan akan terganggu, emosional siswa juga akan terganggu karena efek game ini, jadwal beribadahpun kadang akan di lalaikan oleh siswa, siswa cenderung akan membolos sekolah demi game kasayangan mereka.

Pelajar yang kita maksud di sini adalah seorang anak, baik laki-laki maupun perempuan, berusia 8-17 tahun yang masih menjajaki dunia pendidikan khususnya di tingkat SD, SMP, dan SMA. Siswa, selain mempunyai hak yang harus di terima, juga mempunyai kewajiban yang harus dipenuhinya. Salah satu kewajiban seorang pelajar yang kita ketahui adalah menuntut ilmu dan belajar. Di jaman sekarang kewajiban seorang pelajar mulai terkikis adanya arus globalisasi pada kemajuan teknologi, pelajar lebih menomorduakan belajar dari pada bermain game online, di dalam kesehariannya para pelajar lebih cepat terpengaruh ajakan dari teman-teman, selain ajakan teman-teman rasa penasaran akan sesuatu yang baru lah yang mendorong mereka untuk mencoba mencoba hal-hal yang belum pernah mereka lakukan.

Pelajar sendiri mudah terpengaruh adanya hal hal yang baru, umumnya mereka terpengaruh dari pergaulan, teman teman dari pergaulan tersebut yang mencoba mempengaruhi pelajar trsebut untuk bermain game online. Namun pengaruh tersebut lebih baik daripada diajak untuk kearah lebih negatif seperti mabuk mabukan, judi, narkoba dll. Pada situasi seperti ini, peran orang tua yang lebih bisa dianggap untuk mengatasi masalah tersebut, orang tua dirumah lebih berperan penting dalam mengatur tingkah laku dan kepribadian dari pelajar tersebut, sedangkan orang tua di sekolah lebih diatur untuk mengarahkan kemana pelajar tersebut bergaul.

Banyak penyebab yang ditimbulkan dari kecanduan game online, salah satunya karena gamer tidak akan pernah bisa menyelesaikan permainan sampai tuntas. Selain itu, karena sifat dasar manusia yang selalu ingin menjadi pemenang dan bangga semakin mahir akan sesuatu termasuk sebuah permainan. Dalam game online apabila point bertambah, maka objek yang akan dimainkan akan semakin hebat, dan kebanyakan orang senang sehingga menjadi pecandu. Penyebab lain yang dapat ditelusuri adalah kurangnya pengawan dari orang tua, dan pengaruh globalisai dari teknologi yang memang tidak bisa dihindari. Terdapat faktor internal dan faktor 
eksternal yang menyebabkan adiksi remaja terhadap game online. Faktor-faktor internal yang dapat menyebabkan terjadinya adiksi terhadap game online, sebagai berikut:

1. keinginan yang kuat dari diri remaja untuk memperoleh nilai yang tinggi dalam game online, karena game online dirancang sedemikian rupa agar gamer semakin penasaran dan semakin ingin memperoleh nilai yang lebih tinggi;

2. rasa bosan yang dirasakan remaja ketika berada di rumah atau di sekolah;

3. ketidak mampuan mengatur prioritas untuk mengerjakan aktivis penting lainya juga menjadi penyebab timbulnya adiksi terhadap game online; dan

4. kurangnya self control dalam diri remaja, sehingga remaja kurang mengantisipasi dampak negatif yang timbul dari bermain game online secara berlebihan.

Sedangkan faktor-faktor eksternal yang menyebabkan terjadinya adiksi bermain game online pada remaja, sebagai berikut:

1. lingkungan yang kurang terkontrol, karena melihat teman- temanya yang lain banyak yang bermain game online;

2. kurang memiliki hubungan sosial yang baik, sehingga remaja mememilih alternatif bermain

3. game sebagai aktivitas yang menyenangkan; dan

4. harapan orang tua yang melabung terhadap anaknya untuk mengikuti berbagai kegiatan seperti kursus- kursus atau les-les, sehingga kebutuhan primer anak, seperti kebersaman, bermain dengan keluarga menjadi terlupakan (Laufi Dian Deodo Saputra, Makalah Dampak Game Online Terhadap Kaum Remaja, tersedia: http//ber5aja.blogspot.com/.../dam pak-game-online-terhadap-kaum- remaja. ht.)

Menurut Smart mengemukakan bahwa seseorang suka bermain game online dikarenakan seseorang terbiasa bermain game online melebihi waktu. Beberapa orang tua menjadikan bermain game online sebagai alat penenang bagi anak dan apabila hal itu dilakukan secara berulang-ulang maka anak tersebut akan terbiasa bermain game online adalah sebagai berikut:

a. Kurang perhatian dari orang- orang terdekat

Beberapa orang berfikir bahwa mereka dianggap ada jika mereka mampu mengusai keadaan. Mereka merasa bahagia jika mendapatkan perhatian dari orang-orang terdekatnya, terutama ayah dan ibu. Dalam rangka mendapatkan perhatian, seseorang akan berperilaku yang tidak menyenangkan hati orang tuanya. Karena dengan berbuat demikian, maka orang tua akan memperingatkan dan mengawasinya.

b. Depresi

Beberapa orang menggunakan media untuk menghilangkan rasa depresinya, diantaranya denga bermain game online. Dan dengan rasa nikmat yang ditawarkan game online, maka lama kelamaan akan menjadi kecanduan.

c. Kurang control

Orang tua denga memanjakan anak dengan fasilitas, efek kecanduan sangat mungkin terjadi. Anak yang tidak terkontrol biasanya akan berperilaku over.

d. Kurang kegiatan

Menganggur adalah kegiatan yang tidak menyenangkan. Dengan tidak adanya kegiatan maka bermain game online sering dijadikan pelarian yang dicari.

e. Lingkungan

Perilaku seseorang tidak hanya terbentuk dari dalam keluarga. Saat di sekolah, bermain dengan teman teman itu juga dapat membentuk perilaku seseorang. Artinya meskipun seseorang tidak dikenalkan terhadap game online dirumah, maka seseorang akan kenal dengan game online karena pergaulannya. 


\section{f. Pola Asuh}

Pola asuh orang tua juga sangat penting bagi perilaku seseorang. Maka, sejak dini orang tua harus berhati-hati dalam mengasuh anaknya. Karena kekeliruan dalam pola asuh maka suatu saat anak akan meniru perilaku orang tuanya (Aqila Smart, 2010: 24).

Tempat-tempat game online sekarang sudah banyak dan mudah dijumpai baik di perkotaan atau pun di pedesaan, jadi perkembangannya menjadi lebih mudah. Yang dibahayakan dari dampak game online ini sangat buruk terutama untuk psikis dan fisik pada usia remaja.

Beberapa tips atau solusi cara mengatasi kecanduan game online, antara lain:

1. Bersungguh-sungguh (niat)

Langkah pertama agar bisa berhenti kecanduan harus ada niat dalam diri sendiri yaitu harus bersungguh-sungguh atau berjanji dengan diri anda sendiri tidak akanmain game online lagi, namun awalnya pasti begitu sulit untuk melakukanya, tapi lambat laun pasti akan bisa.

2. Mempunyai pikiran hemat

Dengan menghitung banyaknya uang yang dikeluarkan untuk bermain game online di warnet akan membuat seseorang lebih berpikir untuk tidak menghabiskan uangnya demi game online.

3. Mencari aktivis lain

Mencari aktivitas lain yang positif dan lebih bermanfaat terutama kebiasaan yang disukai, seperti berolahraga, membaca buku atau bereaksi. Sehingga tidak ada waktu kosong untuk bermain game online.

4. Membatasi waktu bermain game online

Mengurangi waktu bermain dengan mulai menentukan jam bermain dan diusahakan mematuhi jadwal tersebut. Untuk tahap awal sehari bermain 3 jam dan untuk hari-hari berikutnya dikurangi sedikit demi sedikit.

5. Jangan bergaul dengan pemain game online

Maksud dari hal ini bukan tidak boleh berteman dengan pemain game melainkan jangan terlalu akrab karena ajakan dan pengaruh teman akan gampang mempengaruhi untuk bermain game online lagi.

6. Meminta bantuan orang terdekat

Maksudnya meminta orang terdekat untuk sementara menjadi pengingat setiap kali hendak ke warnet atau ingin bermain game. Akan sangat baik apabila dia bukan seorang gamers juga (Laufi Dian Deodo Saputra, Makalah Dampak Game Online Terhadap Kaum Remaja, tersedia: http//ber5aja.blogspot.com/.../dampak-game-online-terhadap-kaum- remaja.ht).

Kriteria kecanduan game online sebenarnya hampir sama dengan jenis kecanduan yang lain, akan tetapi kecanduan game online dimasukkan kedalam golongan kecanduan secara fisik. Le mengemukakan bahwa terdapat empat komponen yang menunjukan seseorang kecanduan game online. Keempat kompone tersebut adalah:

1. Compulsion (kompulsif atau dorongan untuk melakukan secara terus menerus) merupakan suatu dorongan atau tekanan kuat yang berasal dari dalam diri sendiri untuk melakukan sesuatu hal secara terus menurus, dimana dalam hal ini merupakan dorongan dari dalam diri untuk terus menurus bermain game online.

2. Withdrawal (penarikan diri) Merupakan suatu upaya untuk menarik diri atau menjauhkan diri dari suatu hal. Seorang yang kecanduan game online merasa tidak mampu untuk menarik atau menjauhkan diri dari hal-hal yang berkenaan dengan game online, seperti halnya seorang perokok yang tidak bisa lepas dari rokok.

3. Tolerance (toleransi)

Toleransi dalam hal ini diartikan sebagai sikap menerima keadaan diri kita ketika melakukan sesuatu hal. Biasanya toleransi ini berkenaan dengan jumlah waktu yang 
digunakan atau dihabiskan untuk melakukan sesuatu yang dalam hal ini adalah bermain game online, dan kebanyakan pemain game online tidak akan berhenti bermain game online tidak akan berhenti bermain hingga merasa puas. 4. Interpersonal and health-related problems (masalah hubungan interpersonal dan kesehatan) Merupakan persoalan-persoalan yang berkaitan dengan interaksi kita dengan orang lain dan juga masalah kesehatan. Pecandu game online cenderung untuk tidak menghiraukan bagaimana hubungan interpersonal yang mereka miliki karena mereka hanya terfokus pada game online saja. Begitu pula dengan masalah kesehatan mereka seperti waktu tidur yang kurang, tidak menjadi kebersihan badan dan pola makan yang tidak teratur

\section{Metode Penelitian}

Jenis penelitian yang digunakan adalah jenis kuantitatif, banyak menggunakan angka, mulai dari pengumpulan data, penafsiran terhadap data tersebut, serta penampilan dari hasilnya. Demikian juga tetap dipakai kesimpulan penelitian menjadi lebih baik apabila disertai dengan tabel, grafik, bagan, gambar atau tampilan lain.

\section{Hasil dan Pembahasan}

Penelitian ini dilaksanakan di MA Al Furqon Prabumulih tahun pelajaran 2015/2016 pada 26 Februari sampai dengan 26 Maret sesuai dengan jadwal yang disepakati. Subjek dalam penelitian ini adalah seluruh peserta didik kelas X MA Al-Furqon Prabumulih sebanyak 53 peserta didik. Karakteristik yang dijadikan sampel penelitian ini adalah peserta didik yang suka bermain game online. Untuk mengetahui karakteristik tersebut peneliti melakukan wawancara terbuka dengan guru BK dan guru kelas $\mathrm{X}$ dari sekolah tersebut untuk mengidentifikasi ada atau tidak adanya peserta didik yang gemar bermain game online.

Setelah melakukan pengumpulan data melalui angket penelitian. Diperoleh data dari responden mengenai variabel faktor- faktor yang mempengaruhi $(X)$ dan variabel perilaku gangguan kecanduan game online (Y). Hal ini dilakukan dengan menyebarkan angket kepada kelas X MA Al-Furqon Prabumulih dengan cara dipandu cara pengisiannya pada setiap item angket sehingga diharapkan mereka mengerti cara pengisiannya. Sampel penelitian ini adalah laki-laki dan perempuan kelas X MA Al-Furqon Prabumulih. Setelah angket disebarkan kepada peserta didik yang menjadi sampel untuk penelitian ini dan kemudian diteliti.

Berdasarkan hasil wawancara tentang faktor-faktor yang mempengaruhi perilaku gangguan kecanduan game online pada peserta didik kelas X di MA Al Furqon Prabumulih, dengan peserta didik kelas $\mathrm{X}$ peneliti memperoleh gambaranbahwa perilaku gangguan kecanduan game online mereka di pengaruhi oleh beberapa faktor di antaranya, kurang perhatian dari orang-orang terdekat, Kurang kontrol, dan depresi. Jadi peserta didik membutuhkan perhatian dari orang tua, keluarga, dan lingkungan serta rangsangan dari luar. Berdasarkan hasil wawancara dengan guru Bimbingan dan Konseling di MA Al Furqon Prabumulih di peroleh gambaran bahwa peserta didik X memang pada kenyataannya prestasi peserta didik cukup rendah, ini dapat dilihat dari nilai peserta didik yang semakin menurun dikarenakan bermain game online.

Dari 53 peserta didik peneliti mengambil 20 peserta didik untuk di wawancara terkait dengan faktor-faktor yang mempengaruhi perilaku gangguan kecanduan game online. Dari enam indikator yang dikemukakan oleh Smart, untuk lebih lebih jelasnya peserta didik yang kecanduan game online akan dirinci dalam tabel berdasarkan indikator yang dikemukakan Smart sebagai berikut: 
Tabel 1. Peserta Didik MA Al Furqon Prabumulih

\begin{tabular}{|r|c|c|c|c|c|c|c|l|}
\hline \multirow{2}{*}{ No } & \multirow{2}{*}{$\begin{array}{c}\text { Nama } \\
\text { Peserta }\end{array}$} & \multicolumn{6}{|c|}{ Faktor-faktor Pengaruh Kecanduan Game Online } & \multirow{2}{*}{ Keterangan } \\
\hline & $\mathbf{1}$ & $\mathbf{2}$ & $\mathbf{3}$ & $\mathbf{4}$ & $\mathbf{5}$ & $\mathbf{6}$ & \\
\hline 1 & A & $\sqrt{ }$ & $\sqrt{ }$ & $\sqrt{ }$ & & $\sqrt{ }$ & $\sqrt{ }$ & Kecanduan \\
\hline 2 & AA & $\sqrt{ }$ & $\sqrt{ }$ & $\sqrt{ }$ & $\sqrt{ }$ & & $\sqrt{ }$ & Kecanduan \\
\hline 3 & AR & $\sqrt{ }$ & $\sqrt{ }$ & $\sqrt{ }$ & $\sqrt{ }$ & $\sqrt{ }$ & $\sqrt{ }$ & Kecanduan \\
\hline 4 & AS & $\sqrt{ }$ & & & $\sqrt{ }$ & $\sqrt{ }$ & & Tidak kecanduan \\
\hline 5 & BS & $\sqrt{ }$ & $\sqrt{ }$ & $\sqrt{ }$ & & $\sqrt{ }$ & $\sqrt{ }$ & Kecanduan \\
\hline 6 & DD & $\sqrt{ }$ & $\sqrt{ }$ & $\sqrt{ }$ & $\sqrt{ }$ & $\sqrt{ }$ & $\sqrt{ }$ & Kecanduan \\
\hline 7 & DR & $\sqrt{ }$ & $\sqrt{ }$ & $\sqrt{ }$ & $\sqrt{ }$ & & $\sqrt{ }$ & Kecanduan \\
\hline 8 & DRD & $\sqrt{ }$ & & $\sqrt{ }$ & & & & Tidak kecanduan \\
\hline 9 & EI & $\sqrt{ }$ & $\sqrt{ }$ & $\sqrt{ }$ & $\sqrt{ }$ & & $\sqrt{ }$ & Kecanduan \\
\hline 10 & ES & $\sqrt{ }$ & $\sqrt{ }$ & $\sqrt{ }$ & $\sqrt{ }$ & $\sqrt{ }$ & $\sqrt{ }$ & Kecanduan \\
\hline 11 & FS & $\sqrt{ }$ & $\sqrt{ }$ & $\sqrt{ }$ & $\sqrt{ }$ & $\sqrt{ }$ & $\sqrt{ }$ & Kecanduan \\
\hline 12 & IA & $\sqrt{ }$ & $\sqrt{ }$ & & & & & Tidak kecanduan \\
\hline 13 & LSA & $\sqrt{ }$ & $\sqrt{ }$ & $\sqrt{ }$ & $\sqrt{ }$ & $\sqrt{ }$ & $\sqrt{ }$ & Kecanduan \\
\hline 14 & MA & $\sqrt{ }$ & $\sqrt{ }$ & $\sqrt{ }$ & $\sqrt{ }$ & $\sqrt{ }$ & $\sqrt{ }$ & Kecanduan \\
\hline 15 & MM & $\sqrt{ }$ & $\sqrt{ }$ & $\sqrt{ }$ & & & & Tidak kecanduan \\
\hline 16 & MWA & $\sqrt{ }$ & $\sqrt{ }$ & $\sqrt{ }$ & & $\sqrt{ }$ & $\sqrt{ }$ & Kecanduan \\
\hline 17 & RA & $\sqrt{ }$ & & $\sqrt{ }$ & $\sqrt{ }$ & $\sqrt{ }$ & $\sqrt{ }$ & Kecanduan \\
\hline 18 & RY & $\sqrt{ }$ & $\sqrt{ }$ & $\sqrt{ }$ & & $\sqrt{ }$ & $\sqrt{ }$ & Kecanduan \\
\hline 19 & WW & $\sqrt{ }$ & $\sqrt{ }$ & $\sqrt{ }$ & $\sqrt{ }$ & & $\sqrt{ }$ & Kecanduan \\
\hline 20 & WP & $\sqrt{ }$ & & $\sqrt{ }$ & & & & Tidak kecanduan \\
\hline
\end{tabular}

Berdasarkan tabel 1 dapat diketahui bahwa terdapat peserta didik yang memiliki permasalahan mengenai faktor-faktor yang mempengaruhi perilaku gangguan kecanduan game online yang disebabkan karena faktor diantaranya adalah kurang perhatian dari orang terdekat, kurang kontrol, dan depresi.

Penelitian ini digunakan untuk memperoleh data mengenai variabel faktor-faktor yang mempengaruhi $(\mathrm{X})$ dan variabel perilaku gangguan kecanduan game online $(\mathrm{Y})$. Hal tersebut dilakukan dengan menyebar angket yang telah ditentukan indikator dan sub indikator nya terlebih dahulu. Setelah melaksanakan penelitian dengan menyebar angket kepada seluruh responden, maka diperoleh data mengenai variabel faktor-faktor yang mempengaruhi $(\mathrm{X})$ dan variabel perilaku gangguan kecanduan game online (Y).

a. Distribusi Frekuensi Faktor- Faktor yang Mempengaruhi (X)

Tabel 2. Distribusi Frekuensi Indikator Kurang Perhatian

\begin{tabular}{|c|c|c|c|}
\hline Kategori & Interval & Frekuensi & Persentase \\
\hline Tinggi & $5-6$ & 35 & $66,04 \%$ \\
\hline Sedang & $3-4$ & 6 & $11,32 \%$ \\
\hline Rendah & $1-2$ & 12 & $22,04 \%$ \\
\hline \multicolumn{2}{|c|}{ Total } & 53 & $100 \%$ \\
\hline
\end{tabular}


Berdasarkan Tabel 2, distribusi frekuensi indikator kurang perhatian menunjukkan bahwa sebanyak 12 peserta didik atau (22,04\%) tergolong dalam kategori rendah, 6 peserta didik atau $22,04 \%$ tergolong dalam kategori sedang, serta 35 peserta didik atau $(66,04 \%)$ tergolong dalam kategori tinggi (mendapat perhatian).

Tabel 3. Distribusi Frekuensi Indikator Depresi

\begin{tabular}{|c|c|c|c|}
\hline Kategori & Interval & Frekuensi & Persentase \\
\hline Tinggi & $12-15$ & 9 & $16,98 \%$ \\
\hline Sedang & $9-11$ & 24 & $45,28 \%$ \\
\hline Rendah & $6-8$ & 20 & $37,74 \%$ \\
\hline \multicolumn{2}{|r|}{ Total } & 53 & $100 \%$ \\
\hline
\end{tabular}

Berdasarkan Tabel 3, distribusi frekuensi indikator depresi menunjukkan bahwa sebanyak 20 peserta didik atau $(37,74 \%)$ tergolong dalam kategori rendah, 24 peserta didik atau $(45,28 \%)$ tergolong dalam kategori sedang, dan 9 peserta didik atau $(16,98)$ tergolong dalam kategori tinggi.

Tabel 4. Distribusi Frekuensi Indikator Kurang Kontrol

\begin{tabular}{|c|c|c|c|}
\hline Kategori & Interval & Frekuensi & Persentase \\
\hline Tinggi & $14-17$ & 22 & $41,51 \%$ \\
\hline Sedang & $11-13$ & 19 & $35,85 \%$ \\
\hline Rendah & $8-10$ & 12 & $22,64 \%$ \\
\hline \multicolumn{2}{|c|}{ Total } & 53 & $100 \%$ \\
\hline
\end{tabular}

Berdasarkan Tabel 4, distribusi frekuensi indikator kurang kontrol menunjukkan bahwa sebanyak 12 peserta didik atau $(22,64 \%)$ tergolong dalam kategori rendah, 19 peserta didik atau $(35,85 \%)$ tergolong dalam kategori sedang, dan 22 peserta didik atau $(41,51 \%)$ tergolong dalam kategori tinggi.

Tabel 5. Distribusi Frekuensi Indikator Kurang Kegiatan

\begin{tabular}{|l|l|c|c|}
\hline Kategori & Interval & Frekuensi & Persentase \\
\hline Tinggi & $13-15$ & 4 & $7,55 \%$ \\
\hline Sedang & $10-12$ & 32 & $60,38 \%$ \\
\hline Rendah & $7-9$ & 17 & $32,07 \%$ \\
\hline \multicolumn{2}{|c|}{ Total } & 53 & $100 \%$ \\
\hline
\end{tabular}

Berdasarkan Tabel 5, distribusi frekuensi indikator kurang kegiatan menunjukkan bahwa sebanyak 17 peserta didik atau $(32,07 \%)$ tergolong dalamkategori rendah, 32 peserta didik atau $(60,38 \%)$ tergolong dalam kategori sedang, dan 4 peserta didik atau $(7,55 \%)$ tergolong dalam kategori tinggi.

Tabel 6. Distribusi Frekuensi Indikator Lingkungan

\begin{tabular}{|c|c|c|c|}
\hline Kategori & Interval & Frekuensi & Persentase \\
\hline Tinggi & $13-15$ & 8 & $15,09 \%$ \\
\hline Sedang & $10-12$ & 37 & $69,82 \%$ \\
\hline Rendah & $7-9$ & 8 & $15,09 \%$ \\
\hline \multicolumn{2}{|r|}{ Total } & 53 & $100 \%$ \\
\hline
\end{tabular}


Berdasarkan Tabel 6, distribusi frekuensi indikator lingkungan menunjukkan bahwa sebanyak 8 peserta didik atau $(15,09 \%)$ tergolong dalamkategori rendah, 37 peserta didik atau $(69,82 \%)$ tergolong dalam kategori sedang, dan 8 peserta didik atau $(15,09 \%)$ tergolong dalam kategori tinggi.

Tabel 7. Distribusi Frekuensi Indikator Pola Asuh

\begin{tabular}{|c|c|c|c|}
\hline Kategori & Interval & Frekuensi & Persentase \\
\hline Tinggi & $25-30$ & 3 & $5,66 \%$ \\
\hline Sedang & $19-24$ & 36 & $67,92 \%$ \\
\hline Rendah & $13-18$ & 14 & $26,42 \%$ \\
\hline \multicolumn{2}{|c|}{ Total } & 53 & $100 \%$ \\
\hline
\end{tabular}

Berdasarkan Tabel 7, distribusi frekuensi indikator pola asuh menunjukkan bahwa sebanyak 14 peserta didik atau $(26,42 \%)$ tergolong dalam kategori rendah, 36 peserta didik atau $(67,92 \%)$ tergolong dalam kategori sedang, dan 3 peserta didik atau $(5,66 \%)$ tergolong dalam kategori tinggi.

b. Distribusi Frekuensi Perilaku Gangguan Kecanduan Game Online (Y)

Tabel 8. Distribusi Frekuensi Indikator Menghabiskan Waktu

\begin{tabular}{|c|c|c|c|}
\hline Kategori & Interval & Frekuensi & Persentase \\
\hline Tinggi & $14-17$ & 31 & 58,495 \\
\hline Sedang & $11-13$ & 10 & $18,87 \%$ \\
\hline Rendah & $8-10$ & 12 & $22,64 \%$ \\
\hline \multicolumn{2}{|c|}{ Total } & 53 & $100 \%$ \\
\hline
\end{tabular}

Berdasarkan Tabel 8, distribusi frekuensi indikator menghabiskan waktu menunjukkan bahwa sebanyak 12 peserta didik atau $(22,64 \%)$ tergolong dalam kategori rendah, 10 peserta didik atau $(18,87 \%)$ tergolong dalam kategori sedang, dan 31 peserta didik atau $(58,49 \%)$ tergolong dalam kategori tinggi.

Tabel 9. Distribusi Frekuensi Indikator Mendapatkan Kesenangan

\begin{tabular}{|c|c|c|c|}
\hline Kategori & Interval & Frekuensi & Persentase \\
\hline Tinggi & $12-14$ & 16 & $30,19 \%$ \\
\hline Sedang & $9-11$ & 22 & $41,51 \%$ \\
\hline Rendah & $6-8$ & 15 & $28,30 \%$ \\
\hline \multicolumn{2}{|c|}{ Total } & 53 & $100 \%$ \\
\hline
\end{tabular}

Berdasarkan Tabel 9, distribusi frekuensi indikator mendapatkan kesenangan menunjukkan bahwa sebanyak 15 peserta didik atau $(28,30 \%)$ tergolong dalam kategori rendah, 22 peserta didik atau $(41,51 \%)$ tergolong dalam kategori sedang, dan 16 peserta didik atau $(30,19 \%)$ tergolong dalam kategori tinggi. 
Tabel 10. Distribusi Frekuensi Indikator Tidak Peduli

\begin{tabular}{|c|c|c|c|}
\hline Kategori & Interval & Frekuensi & Persentase \\
\hline Tinggi & $21-26$ & 20 & $37,73 \%$ \\
\hline Sedang & $16-20$ & 22 & $41,51 \%$ \\
\hline Rendah & $11-15$ & 11 & $20,76 \%$ \\
\hline \multicolumn{2}{|r|}{ Total } & 53 & $100 \%$ \\
\hline
\end{tabular}

Berdasarkan Tabel 10, distribusi frekuensi indikator tidak peduli menunjukkan bahwa sebanyak 11 peserta didik atau $(20,76 \%)$ tergolong dalam kategori rendah, 22 peserta didik atau $(41,51 \%)$ tergolong dalam kategori sedang, dan 20 peserta didik atau $(37,73 \%)$ tergolong dalam kategori tinggi.

Tabel 11. Distribusi Frekuensi Indikator Merasa Marah/Depresi

\begin{tabular}{|c|c|c|c|}
\hline Kategori & Interval & Frekuensi & Persentase \\
\hline Tinggi & $8-9$ & 16 & $30,19 \%$ \\
\hline Sedang & $6-7$ & 22 & $41,51 \%$ \\
\hline Rendah & $4-5$ & 15 & $28,30 \%$ \\
\hline \multicolumn{2}{|c|}{ Total } & 53 & $100 \%$ \\
\hline
\end{tabular}

Berdasarkan Tabel 11, distribusi frekuensi indikator merasa marah/depresi menunjukkan bahwa sebanyak 15 peserta didik atau $(28,30 \%)$ tergolong dalam kategori rendah, 22 peserta didik atau $(41,51 \%)$ tergolong dalam kategori sedang, dan 16 peserta didik atau $(30,19 \%)$ tergolong dalam kategori tinggi.

Tabel 12. Distribusi Frekuensi Indikator Rasa Kebutuhan

\begin{tabular}{|c|c|c|c|}
\hline Kategori & Interval & Frekuensi & Persentase \\
\hline Tinggi & $8-9$ & 22 & $41,51 \%$ \\
\hline Sedang & $6-7$ & 20 & $37,73 \%$ \\
\hline Rendah & $4-5$ & 11 & $20,76 \%$ \\
\hline \multicolumn{2}{|c|}{ Total } & 53 & $100 \%$ \\
\hline
\end{tabular}

Berdasarkan Tabel 12, distribusi frekuensi indikator rasa kebutuhan menunjukkan bahwa sebanyak 11 peserta didik atau $(20,76 \%)$ tergolong dalam kategori rendah, 20 peserta didik atau $(37,73 \%)$ tergolong dalam kategori sedang, dan 22 peserta didik atau $(41,51 \%)$ tergolong dalam kategori tinggi.

Tabel 13. Distribusi Frekuensi Indikator Berbohong

\begin{tabular}{|c|c|c|c|}
\hline Kategori & Interval & Frekuensi & Persentase \\
\hline Tinggi & $12-14$ & 12 & $22,64 \%$ \\
\hline Sedang & $9-11$ & 24 & $45,28 \%$ \\
\hline Rendah & $6-8$ & 17 & $32,08 \%$ \\
\hline \multicolumn{2}{|c|}{ Total } & 53 & $100 \%$ \\
\hline
\end{tabular}

Berdasarkan Tabel 13, distribusi frekuensi indikator berbohong menunjukkan bahwa sebanyak 17 peserta didik atau $(32,08 \%)$ tergolong dalamkategori rendah, 24 peserta didik atau(45,28\%) tergolong dalam kategori sedang, dan 12 peserta didik atau $(22,64 \%)$ tergolong dalam kategori tinggi. 
Tabel 14. Distribusi Frekuensi Indikator Rendahnya Prestasi

\begin{tabular}{|c|c|c|c|}
\hline Kategori & Interval & Frekuensi & Persentase \\
\hline Tinggi & $8-9$ & 17 & $32,07 \%$ \\
\hline Sedang & $6-7$ & 25 & $47,17 \%$ \\
\hline Rendah & $4-5$ & 11 & $20,76 \%$ \\
\hline \multicolumn{2}{|c|}{ Total } & 53 & $100 \%$ \\
\hline
\end{tabular}

Berdasarkan Tabel 14, distribusi frekuensi indikator rendahnya prestasi menunjukkan bahwa sebanyak 11 peserta didik atau (20,76\%) tergolong dalam kategori rendah, 25 peserta didik atau $(47,17 \%)$ tergolong dalam kategori sedang, dan 17 peserta didik atau $(32,07 \%)$ tergolong dalam kategori tinggi.

Tabel 15. Distribusi Frekuensi Indikator Tidak Peduli Melanggar Aturan

\begin{tabular}{|c|c|c|c|}
\hline Kategori & Interval & Frekuensi & Persentase \\
\hline Tinggi & $12-14$ & 9 & $16,98 \%$ \\
\hline Sedang & $9-11$ & 27 & $50,94 \%$ \\
\hline Rendah & $6-8$ & 17 & $32,08 \%$ \\
\hline \multicolumn{2}{|c|}{ Total } & 53 & $100 \%$ \\
\hline
\end{tabular}

Berdasarkan Tabel 15, distribusi frekuensi indikator tidak peduli melanggar aturan menunjukkan bahwa sebanyak 17 peserta didik atau $(32,08 \%)$ tergolong dalam kategori rendah, 27 peserta didikatau $(50,94 \%)$ tergolong dalam kategori sedang, dan 9 peserta didik atau $(16,98 \%)$ tergolong dalam kategori tinggi.

Hasil Analisis Bivariat (Uji Hipotesis)

Tabel 16. Daftar Kontingensi Faktor-Faktor yang Mempengaruhi (X) terhadap perilaku angguan Kecanduan Game Online (Y)

\begin{tabular}{|l|c|c|c|c|}
\hline $\begin{array}{l}\text { Faktor-Faktor } \\
\text { Perilaku } \\
\text { Gangguan (Y) }\end{array}$ & Pengaruh & $\begin{array}{c}\text { Cukup } \\
\text { Berpengaruh }\end{array}$ & $\begin{array}{c}\text { Kurang } \\
\text { Berpengaruh }\end{array}$ & Jumlah \\
\hline Tinggi & 8 & 5 & 0 & 13 \\
\hline Sedang & 0 & 25 & 3 & 28 \\
\hline Rendah & 0 & 1 & 11 & 12 \\
\hline \multicolumn{1}{|c|}{ Jumlah } & 8 & 31 & 14 & $\mathbf{5 3}$ \\
\hline
\end{tabular}


Pengujian Data

Pengujian Faktor-Faktor yang Mempengaruhi (X) terhadap Perilaku Gangguan Kecanduan Game Online (Y)

$$
\begin{aligned}
& X^{2}=\sum_{i=j}^{B} \sum_{j=i}^{K} \frac{(O i j-E i j)^{2}}{E i j} \\
& \mathrm{E}_{11}=\frac{(8 \times 13)}{53} \\
& \mathrm{E}_{21}=\frac{(31 \times 13)}{53} \\
& =7,60 \\
& \mathrm{E}_{12}=\frac{(8 \times 28)}{53} \\
& =4,23 \\
& \mathrm{E}_{22}=\frac{(31 \times 28)}{53} \\
& =16,37 \\
& \begin{aligned}
\mathrm{E}_{13} & =\frac{(8 \times 12)}{53} \\
& =1,81
\end{aligned} \\
& \mathrm{E}_{23}=\frac{(31 \times 12)}{53} \\
& =7,02 \\
& \begin{aligned}
\mathrm{E}_{31} & =\frac{(14 \times 13)}{53} \\
& =3,43
\end{aligned} \\
& \mathrm{E}_{32}=\frac{(14 \times 28)}{53} \\
& =7,40 \\
& \mathrm{E}_{33}=\frac{(14 \times 12)}{53} \\
& =3,17
\end{aligned}
$$

\begin{tabular}{|c|c|c|c|c|}
\hline $\begin{array}{l}\text { Faktor-Faktor } \\
\text { Perilaku } \\
\text { Gangguan (Y) }\end{array}$ & Pengaruh & $\begin{array}{c}\text { Cukup } \\
\text { Berpengaruh }\end{array}$ & $\begin{array}{c}\text { Kurang } \\
\text { Berpengaruh }\end{array}$ & Jumlah \\
\hline Tinggi & & 7,60 & 3,43 & 13 \\
\hline Sedang & & & 7,40 & 28 \\
\hline Rendah & 1,81 & & 3,17 & 12 \\
\hline Jumlah & 8 & 31 & 14 & 53 \\
\hline
\end{tabular}

Selanjutnya dibuat daftar kontingensi sebagai berikut:

Tabel 17. Daftar Kontingensi Perolehan Data Faktor-Faktor yang Mempengaruhi (X) terhadap Perilaku Gangguan Kecanduan Game Online (Y)

Sumber: Analisi Data Primer 2016

Langkah selanjutnya memasukkan data tersebut ke dalam rumus Chi Kuadrat sebagai berikut: 


$$
\begin{aligned}
& X^{2}=\sum_{i=j}^{B} \sum_{j=i}^{K} \frac{(O i j-E i j)^{2}}{E i j} \\
& \begin{aligned}
\mathrm{X}^{2} \quad & \frac{(8-1,96)^{2}}{1,96}+\frac{(0-4,23)^{2}}{4,23}+\frac{(0-1,81)^{2}}{1,81}+\frac{(5-7,60)^{2}}{7,60}+\frac{(25-16,37)^{2}}{16,37}+\frac{(1-7,02)^{2}}{7,02} \\
= & \frac{(0-3,43)^{2}}{3,43}+\frac{(3-7,40)^{2}}{7,40}+\frac{(11-3,17)^{2}}{3,17} \\
= & 18,61+4,23+1,81+0,89+4,55+5,16+3,43+2,62+19,34 \\
= & 60,64 \\
\text { Dengan derajat kebebasan (dk) } & =(\mathrm{b}-1)(\mathrm{k}-1) \\
& =(3-1)(3-1) \\
& =4
\end{aligned}
\end{aligned}
$$

Rumusan hipotesis yang dipakai adalah sebagai berikut:

Ho: Tidak ada faktor-faktor yang mempengaruhi (X) perilaku gangguan kecanduan game online (Y)

Ha: Ada faktor-faktor yang mempengaruhi $(\mathrm{X})$ perilaku gangguan kecanduan game online (Y)

Kriteria pengujian hipotesis yang dipakai adalah sebagai berikut:

a. Jika $X^{2}<$ Xtabel, maka Ha ditolak

b. Jika $X^{2}>$ Xtabel, maka Ha diterima

Berdasarkan hasil perhitungan, didapat $\mathrm{X}^{2}$ hitung 60,64; kemudian dikonsultasikan dengan Chi Kuadrat pada taraf signifikan $5 \%(0,05)$ dan derajat kebebasan $=4$, maka diperoleh $\mathrm{X}^{2}$ tabel $=$ 9,48 . Dengan demikian $X^{2}$ hitung $>X^{2}$ tabel atau 60,64 $>9,48$. Jadi, ada faktorfaktor yang mempengaruhi $(\mathrm{X})$ perilaku gangguan kecanduan game online (Y). Dengan kata lain, hipotesis penelitian diterima.

Pengujian Tingkat Keeratan

Untuk mengetahui derajat asosiasi atau ketergantungan factor-faktor yang mempengaruhi (X) terhadap perilaku gangguan kecanduan game online (Y) digunakan rumus Koefisien Kontingensi C sebagai berikut:

$$
\begin{aligned}
& \mathrm{C}=\sqrt{\frac{X^{2}}{X^{2}+n}} \\
& \mathrm{C}=\sqrt{\frac{60,64}{60,64+53}}=\mathrm{C}=\sqrt{\frac{60,64}{113,64}} \\
& \mathrm{C}=\sqrt{0,534} \\
& \mathrm{C}=0,730
\end{aligned}
$$

Kemudian harga $\mathrm{C}$ dibandingkan dengan koefesien kontingensi maksimum dengan rumus sebagai berikut:

$$
\begin{aligned}
& \mathrm{C}_{\text {maks }}=\sqrt{\frac{M-1}{M}} \\
& \mathrm{C}_{\text {maks }}=\sqrt{\frac{3-1}{3}} \\
& \mathrm{C}_{\text {maks }}=\sqrt{\frac{2}{3}} \\
& \mathrm{C}=\sqrt{0,667} \\
& \mathrm{C}=0,817
\end{aligned}
$$


Berdasarkan hasil di atas, diketahui koefesien kontingensi $\mathrm{C}=0,730$ dan $\mathrm{Cmaks}=0,817$, kemudian dijadikan patokan untuk menentukan ingkat keeratan pengaruh dengan langkah sebagai berikut:

$$
\begin{aligned}
\text { E }_{\text {KAT }} & =\frac{c}{C_{\text {maks }}} \\
& =\frac{0,730}{0,817} \\
& =0,894
\end{aligned}
$$

Sehingga diperoleh klasifikasi atau

pengkategorian sebagai berikut:

$0,00-0,27$ : kategori kurang erat

$0,28-0,55$ : kategori cukup erat

$0,56-0,83$ : kategori erat

$0,84-1,00$ : kategori sangat erat

Berdasarkan pembagian antara nilai $\mathrm{C}=0,730$ dengan $\mathrm{Cmaks}=0,817$, diperoleh nilai 0,89. Dengan demikian, angka tersebut berada pada kategori sangat erat. Hal ini menunjukkan ada faktor-faktor yang mempengaruhi (X) perilaku gangguan kecanduan game online (Y).

\section{Simpulan dan Saran}

Berdasarkan pada kajian teori dan didukung dengan hasil analisis data dan mengacu pada perumusan masalah yang telah diuraikan, maka dapat disimpulkan bahwa: Adanya pengaruh kurangnya perhatian keluarga dengan perilaku gangguan kecanduan game online. Dilihat dari hasil analisis distribusi frekuensi indikator kurang perhatian menunjukkan bahwa sebanyak 12 peserta didik atau (22,64 \%) tergolong dalam kategori rendah, 6 peserta didik atau (11.32 $\%)$ tergolong dalam kategori sedang, dan 35 peserta didik atau $(66,04 \%)$ tergolong dalam kategori tinggi. Adanya pengaruh depresi dengan perilaku gangguan kecanduan game online. Dilihat dari hasil analisis distribusi frekuensi indikator depresi menunjukkan bahwa sebanyak 20 peserta didik atau $(37,74 \%)$ tergolong dalam kategori rendah, 24 peserta didik atau $(45,28$ $\%)$ tergolong dalam kategori sedang, dan 9 peserta didik atau $(16,98 \%)$ tergolong dalam kategori tinggi. Adanya pengaruh kurangnya kontrol keluarga dengan perilaku gangguan kecanduan game online. Dilihat dari hasil analisis distribusi frekuensi indikator kurang kontrol menunjukkan bahwa sebanyak 12 peserta didik atau $(22,64 \%)$ tergolong dalam kategori rendah, 19 peserta didik atau $(35,85 \%)$ tergolong sedang, dan 22 peserta didik atau $(41,51 \%)$ tergolong dalam kategori tinggi. Adanya pengaruh kurangnya kegiatan peserta didik dengan perilaku gangguan kecanduan game online. Dilihat dari hasil analisis distribusi frekuensi indikator kurang kegiatan menunjukkan bahwa sebanyak 17 peserta didik atau $(32,07 \%)$ tergolong dalam kategori rendah, 32 peserta didik atau $(60,38 \%)$ tergolong dalam kategori sedang. dan 4 peserta didik atau $(7,55 \%)$ tergolong dalam kategori tinggi. Adanya pengaruh lingkungan peserta didik dengan perilaku gangguan kecanduan game online. Dilihat dari hasil analisis distribusi frekuensi indikator lingkungan menunjukkan bahwa sebanyak 8 peserta didik atau $(15,09 \%)$ tergolong dalam kategori rendah, 37 peserta didik atau $(69,82 \%)$ tergolong dalam kategori sedang, dan 8 peserta didik atau $(15,09 \%)$ tergolong dalam kategori tinggi. Adanya pengaruh pola asuh yang didapatkan peserta didik dengan perilaku gangguan kecanduan game online. Dilihat dari hasil analisis distribusi frekuensi indikator pola asuh menunjukkan bahwa sebanyak 14 peserta didik atau $(26,42 \%)$ tergolong dalam kategori rendah, 36 peserta didik atau (67,92 \%) tergolong dalam kategori sedang, dan 3 peserta didik atau (5,66\%) tergolong dalam kategori tinggi. 


\section{Daftar Pustaka}

Alquran dan terjemahnya. Bandung: CV Di Penogoro. 2005.

Aderson. Pengaruh lingkungan game online terhadap anak. Yogyakarta: Pustaka Pelajar. 2007.

Angela. Pengaruh Game Online Terhadap Motivasi Belajar Siswa SDN 015 Kelurahan Sidomulyo Kecamatan Samarinda Ilir. ejournal Ilmu Komunikasi. Vol. 1. No. 2. 2013. h.533. tersedia: https://www.scribd.com/../Jurnal-PDF-07-16-13-03-1, [diakses pada tanggal 28 oktober 2015 jam 15.00]

Anandri Rezky Dwie. Orang Tua Dengan Pola Asuh Permisif \& Resiko Anak Kecanduan Game Online. Tersedia: http://dwirezkyanandari.blogspot.com/2014/11/orangtuadengan-pola-asuh-permisif.html.[diakses pada tanggal 10 Oktober 2015]

Arikunto, Suharsimi. Prosuder Penelitian Suatu Pendekatan Praktis. Jakarta: Rineka Cipta. 2010.

Erman Amti dan Prayitno. Dasar-Dasar Bimingan dan Konseling. Jakarta: Rineka Cipta. 2004.

Deodo Laufi Dian Saputra. makalah dampak game online terhadap kaum remaja. tersedia: http// ber5aja.blogspot.com/.../dampak-game-online-terhadap-kaumremaja.ht..,[diakses pada tanggal 28 oktober 2015 jam 15.00]

Feprinca Dica. Hubungan Motivasi Bermain Game Online Pada Masa Dewasa Awal Terhadap Perilaku Kecanduan Game Online Defence Of Ancients (DotA 2). tersedia: http://psikologi.ub.ac.id/wp-content/ .../09/JURNAL8.pdf, [diakses pada tanggal 10 Oktober 2015 jam 16:00]

Gaol Lumban Theresia. Hubungan Kecanduan Game Online Dengan Prestasi Akademik Mahasiswa Di Fakultas Teknik Universitas Indonesia. tersedia:http//,lontar.ui.ac.id/file?file...Huungan\%20kecanduan.pdf[diakses pada tanggal 29 Januari 2016 jam 15.33]

Iyannehemiah. Dampak Game Online Bagi Pelajar. Tersedia: https://iyannehemiah.wordpress.com/[dikases pada tanggal 10 oktober 2015 jam 18.00]

Kuswana, Sunaryo Wowo. Biopsikologi Pembelajaran Perilaku. Bandung: Alfabeta. 2014.

Lindzey,G, dan Hall C,S. Teori-teori Holistik Organismik. Jakarta: 1994.

Mardalis. Metode Penelitian Suatu Pendekatan Proposal. Jakarta: Bumi Aksara. 2004.

Mustofa,Heri. Bikin Game Flash 3D dengan Aplikasi Gratisan. Yogyakarta: ANDI. 2014.

Nani M. Sugandhi dan Syamsu Yusuf L.N. Perkembangan Peserta Didik. Jakarta: PT Grafindo Persada. 2011.

Nofrita, Ade. Mahasiswa Yang Menggunakan Internet Secara Berlebihan Fakultas Psikologi. Jakarta: 2009. 
Permainan Daring-Wikepedia Bahasa Indonesia Ensiklopedia. tersedia: https://id.m.wikipedia.org> wiki.Permainan daring.com. [diakses pada tanggal 8 Oktober 2015 jam 10.00]

Santoso Whitney Trecy. Perilaku Kecanduan Permainan Internet Dan Faktor Penyebabnya Pada Siswa Kelas VIII. Vol 2. No. 2. 2013. tersedia: http://journal.unnes.ac.id/ ../2949 [diakses pada tanggal 29 Janurai 2016 jam 13:00]

Santoso Whitny Trecy. Perilaku Kecanduan Permainan Internet Dan Faktor Penyebab Pada Siswa Kelas VIII DI SMP Negeri 1 Jatisrono Kabupaten Wonogiri(Studi Kasus Pada Siswa Kelas VIII Di SMP Negeri 1 Jatisrono Kabupaten Wonogiri). tersedia: http// lib.unnes.ac.id/17403/1/1301408036.pdf, [diakses pada tanggal 10 Oktober 2015 jam 12.30]

Smart Aqila, Cara Cerdas Mengatasi Anak Kecanduan Game, Jogjakarta, A plus books, 2010.

Sudijono, Anas. Pengantar Statistik Pendidikan. Jakarta: PT. Raja Grafindo Persada. 2011.

Sugiyono, Metode Penelitian Pendidikan (Pendekatan Kuantitatif, Kualitatif dan R\&D), Bandung: Alfabeta. 2012.

Sukardi, Metode Penelitian Pendidikan (Kompetensi dan Praktiknya).Yogyakarta: Bumi Aksara 2003 .

Rosidi David. Contoh Makalah Pengaruh Game Online Terhadap. tersedia: http:// davidrosidi.blogspot.com, [diakses pada tanggal 10 Oktober 2015 jam 18.00]

Triton dan Hariwijaya. Pedoman Penulisan Ilmiah Proposal dan Skripsi. Yogyakarta: Tugu Publisher. 2008

Wati Herlia. Metodelogi Penelitian. Tersedia: http://herliamr. blogspot.com/2012/05/ babiv.html, [diakses tanggal 06 Oktober 2015, jam 7.30].

Willis. Makalah Game. tersedia: http// Willis.himatif.or.id/download/MAKALAH\% 20GAME\%20 ONLINE.doc,diakses tanggal 09 Oktober 2015 jam 09.00]

Yahya Muhammad. Pengaruh Game Online Terhadap Prestasi Belajar Siswa. Tersedia: http:// www.kompasiana.com/sahriramadan/pengaruh-game-online-terhadap-pr...,pada tanggal 10 Oktober 2015 jam 20.00]

Yanto Riki. Pengaruh lingkungan game online terhadap anak (Studi Kasus Pada 5 Orang Remaja Pelaku Game Online di Kelurahan Air Tawar Barat Kecamatan Padang Utara Kota Padang). tersedia: http://repository.unand.ac.id/id/eprint/16852,[diakses pada tanggal 28 oktober 2015 jam 15.00]

Zardian Ardi. Konseling Online: Sebuah Pendekatan Teknologi Dalam Pelayanan Konseling. ejournal konseling dan pendidikan, Vol. 1, No. 1, 2013, h. 1-5, tersedia: http:// jurnal.konselingindonesia.com/index.php/jkp/.../1,[diakses pada tanggal 10 Oktober 2015 jam 12.30] 